In previous world wars, the Red Cross distributed cigarettes to soldiers. The Kosovar refugee crisis has seen this issue rise again, when the Red Cross refused to distribute directly cigarettes and other government agencies took over the role. Tobacco control activists have been drawn into the debate. In Fune, a correspondent to Globalink wrote: "To put soldiers at additional danger by encouraging their smoking during times of stress and war is extremely exploitative and should be strongly discouraged. . . All offers of free cigarettes for soldiers/refugees or any group of people under stressful conditions needs to be determinedly discouraged and stopped as a practice. It is yet again a very transparent means of getting recruits to smoking addiction."

The issue of smoking by refugees and others in dire circumstances, and the tobacco control community's ways of participating in the debates that arise here, deserve debate. Refugees are people who typically are fleeing horrendous circumstances like war or racial persecution. They arrive in host nations or in camps usually without any resources, often having had loved ones killed, and sometimes being tortured. Civilised societies give them support in the form of food, clothing, and shelter and some comforts and small luxuries. Sometimes these people are smokers and well meaning aid workers have provided them with cigarettes.

Below we reprint an exchange between Stan Shatenstein, editor of Canada's Tobacco News Online, and Mark Steyn, columnist for the National Post. We invite your comments via our eletters. - ED

\title{
Should refugees be given cigarettes by aid agencies?
}

From Stan Shatenstein, Tobacco Nerws Online, Montreal. First published as a letter to the Toronto Sun May 22, 1999.

Truth-that eternal first casualty of war-has again gone up in smoke and, this time, Sun columnist Connie Woodcock has lit the match. In an attempt to bring succour to the Kosovar refugees at CFB (Canadian Forces Base) Trenton (Smoke-free refugee camps, Toronto Sun, May 22), Woodcock regrettably revives a number of hoary myths and half truths about tobacco use.

For Woodcock, the Red Cross' refusal to directly supply cigarettes to the Kosovars is "less than kind. It is closer to being small and mean". And, yet, in all news reports, the Red Cross has recognised the refugees' addiction and will allow other groups to provide them with cigarettes. Where is the great cruelty?

Woodcock would have tobacco treated as medicine, citing nicotine's "calming effect on people who are stressed out". What smoking really calms is the brain's craving for more nicotine, a chemical to which it's addicted. The Red Cross has recognised the pharmacological neediness of the refugees, but why should a health agency be turned into a drug dispensary for a harmful product?

We can count ourselves rather fortunate, in this country, that prevention of tobacco use remains the biggest health crisis we face, though it is a huge one. No one in Canada would rather confront the daily prospect of bombardment, displacement, rape, torture, and murder. Tragically, the fate of the Kosovars is not unique, but it is uncommon. The terrible harm caused by smoking is neither instant nor dramatic, but it is ubiquitous and numbing. It does not light up our TV screens with its barbarous ferocity and, yet, this year, as every other year, thousands more Canadians will die prematurely from tobacco use than from any other cause.

Beyond her ill measured anger, Woodcock also confuses the issue concerning the rights of non-smokers. Bans on smoking in hospices and prisons, which she deplores, serve a valuable purpose, regardless of any implementation problems. That has nothing to do with the Kosovar refugees, none of whom appears to be angry with the Red Cross for its no tobacco policy.

How can Woodcock argue that we're trying to "force our morals and standards on others, especially when we're holding them prisoner"? The Kosovars would undoubtedly rather be home, living in peace, but that's not possible. They certainly value the safety they've found here and, contrary to Woodcock's absurd assertions, are not our "prisoners" and are not likely to be "wondering just how free a country Canada is anyway".

Obtaining cigarettes should be their biggest problem. (Incidentally, Woodcock shows she's badly out of touch when she blithely proffers a "du Maurier Ultra Light King Size". The refugees are craving heavier Turkish blends.)

The tragedy of Kosovo is near unspeakable, but so is that of tobacco. Little bombs explode, one lung at a time, one coronary artery at a time, in one family at a time. As Woodcock admitted, "when the Red Cross handed out cigarettes during World War II, we didn't then know about the dangers of smoking". Now we know, so we must do better. The Kosovars are here seeking refuge from quick, ghastly means of annihilation. The Red Cross should not be the agency of a slow, horrid death for the scarred survivors who have joined us here in Canada. 
Spare the refugees from death by smoking On Fune 3, 1999, columnist Mark Steyn responded to Shatenstein's letter in his column in the National Post.

War is hell. Just ask the Bosnians. In 1995, Linda McCartney donated 22 tonnes of dehydrated veggiburger mix to the strife torn former Yugoslav republic only to discover, after it had arrived, that it contained twice as much fat content as advertised. Lady McCartney was aghast. But she quickly swung into action, organising a massive relief effort to get the food recalled. The dangers of excessive cholesterol intake in a war zone are well known. You might keel over from a massive heart attack before Slobo's Serb irregulars have finished mutilating you.

Now the same humanitarian concern has manifested itself at CFB Trenton and the other Canadian bases welcoming Kosovar refugees. Although $98 \%$ of the Kosovars, like most Eastern Europeans, are smokers, the Red Cross has declined to provide them with cigarettes. Since the tales of uptight, nervy, twitchy refugees prowling the perimeter fence in search of a sympathetic passerby who could nip down to Loblaw's for a pouch of Balkan Sobranie first began to seep out, the Red Cross has been at pains to deny that it's subjecting its charges to cruel and unjust punishment. True, they won't supply the Kosovars with cigarettes themselves, and under Canadian law the tobacco companies are in the unusual position of being forbidden to give away a perfectly legal product. But, if Joe Schmoe wants to toss the odd pack of Craven As over the wire, the Red Cross is prepared to look the other way. Craven, eh?

In a letter to The Toronto Sun, the editor of Tobacco News Online, Stan Shatenstein, pointed out that what's happening in Balkan villages and what's happening in Balkan lungs aren't so very different. "The tragedy of Kosovo is near unspeakable, but so is that of tobacco. Little bombs explode, one lung at a time, one

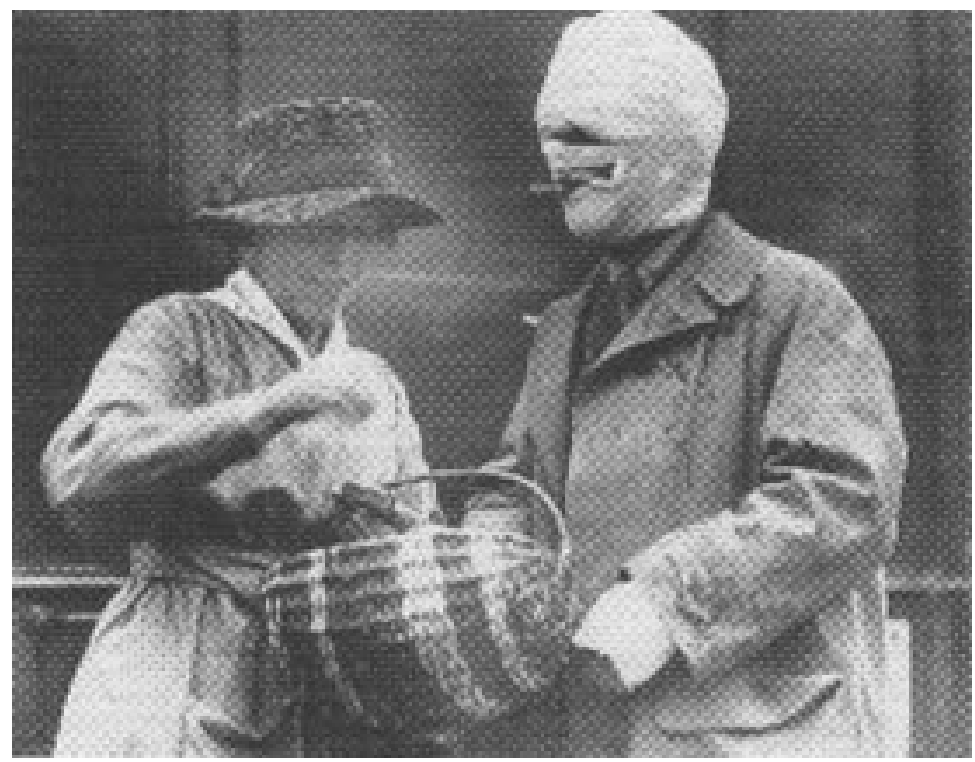

One of thousands of Red Cross volunteers who distributed cigarettes to injured troops in France during the first world war. Source: National Archives, USA. coronary artery at a time, in one family at a time," said Stan. "The Kosovars are here seeking refuge from quick, ghastly means of annihilation. The Red Cross should not be the agency of a slow, horrid death for the scarred survivors who have joined us here in Canada." What a chump that Slobo is. If only he'd bombarded Kosovo with discount cartons of du Maurier Lights, he could have carried on a "slo mo" delayed action ethnic cleansing, and the West would never have noticed.

At this point, I should declare that I'm not one of those conservatives for whom being militantly anti-anti-smoking is a badge of honour. In Washington during the impeachment trial, I turned up at a restaurant with my colleague David Frum and several other distinguished right wing crazies. "Smoking or non-smoking?" asked the hostess. "Smoking, of course!" snapped the fellow from National Review. "Preferably a table in a narrow low ceilinged windowless corridor with Edward $\mathrm{R}$ Murrow and Humphrey Bogart in the next booth wreathed in something Turkish and untipped." (I'm quoting from memory.) Naturally, none of us actually smoked.

But I must say, now that the "Shatenstein Tendency" is so dominant in Canadian life, I'm toying with starting up a 60 a day habit. The Shatensteins seem to have missed the essential difference between death from Slobo and death from smoking. If you're mooching around the barn one morning when the Serbs pull up, rape your wife and daughters and disembowel you, your diminished life expectancy is involuntary; but if, on the other hand, you decide to nip round the back of the barn for a quiet smoke, your diminished life expectancy is the conscious choice of a free individual. And, indeed, an entirely reasonable choice. The lifetime risk of getting lung cancer from smoking is one in 10. By comparison, in major North American cities, the rate of HIV infection among homosexual men is over $50 \%$, but we don't fret about a one in two lifetime risk of getting HIV from gayness. Instead, we hand out condoms. A condom has a failure rate of over $15 \%$ - for pregnancy, that is; for sexually transmitted agents the rate is over $30 \%$. That's not like smoking. That's not a distant deferred risk down the road for a guy with a 20 condom a day habit for five decades. That's the risk on the condom you're wearing now. Yet subjecting yourself to that risk is regarded as being "responsible".

Why are smokers the only fellows who can't be trusted to be "responsible"? Well, there's always the risk to others of "second hand smoke"-a scientifically unproven myth whose promotion by governments makes us look every bit as irrational and superstitious as those backward Balkan types. If there were anything to it, the whole of Eastern Ontario would have keeled over by now from second hand smoke drifting across the border from nicotine shrouded Quebec. In fact, the statistics tell their own story. In fastidious smoke free Ontario, average life expectancy is 79; in Quebec, where we puff away to our heart's content, it's 78 . To gamble 12 months 


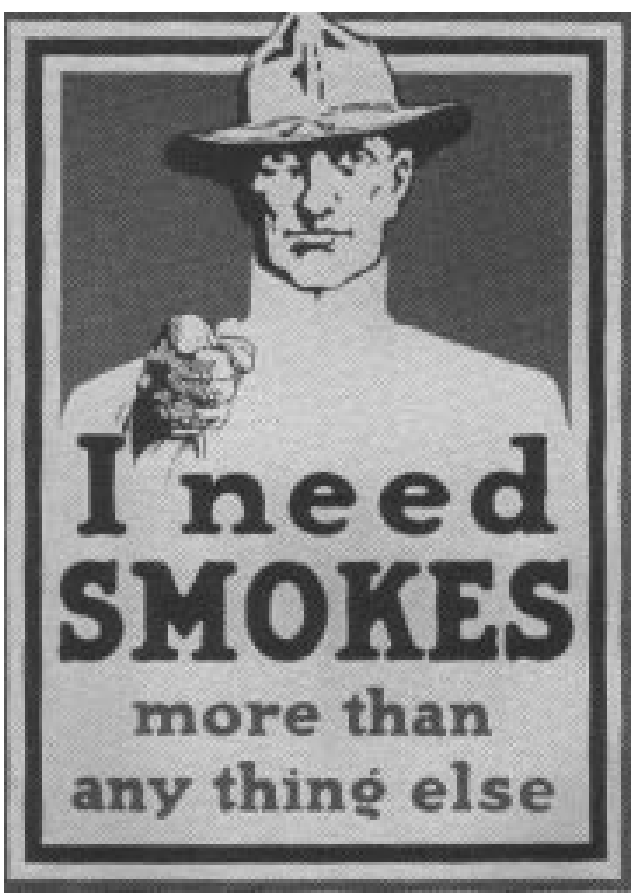

Army poster distributed by the Our Boys in France Tobacco Fund, 1918. Source: Hoover Institution Archives.

for the pleasures of being able to enjoy a relaxing smoke at the end of a night out is a rational human choice. Incidentally, in Albania and Macedonia, where many of those Kosovars who manage to escape CFB Trenton will wind up, average life expectancy is 73 . Albania is the unhealthiest country in Europe; a decayed, impoverished, lawless, nasty little basket case of a state, where, in recent years, smoking has increased by $20 \%$. Yet Albanian life expectancy is closing in on Canada's.

Over here, meanwhile, the aptly named seniors publication CARP News recently reported what it called the "astounding" statistic that $40 \%$ of our senior citizens are regular drinkers. This dramatic figure, they say, would place an increasing strain on the health system as our hospitals struggle to cope with alcohol exacerbated rheumatism, heart disease, and dementia. At least any Albanian who makes it past 74 won't have to put up with a lecture from the nanny state every time he cracks open a bottle of Baby Duck. The real threat to our nation's health would seem to be from non-alcohol exacerbated dementia.

A few weeks ago, billboards went up in Los Angeles showing my old friend Sammy Davis $\mathrm{Jr}$ on stage in Vegas. "He took our breath away," said the poster. "The tobacco companies took his away." Oh, phooey. Sam's life wasn't a tragedy. He smoked it up, boozed it up, had chicks a go go, played Broadway, made movies, topped the hit parade, and headlined at hitherto whites only supper clubs. For a short, one eyed, ugly black guy of his generation, he had a better life than he could ever have expected. I'd rather have had Sam's 64 years than ... well, I was going to name some non-smoking vegetarian nonagenarian but I can't think of any.
I wouldn't be so boorish as to put up a billboard attributing Linda McCartney's early death to her gloomy vegetarian diet. Free born citizens should be entitled to assess their own "lifestyle choices". Sammy Davis understood his weaknesses. As he ruefully reflected, "What kind of fool am I?" As they pad around CFB Trenton gasping for a smoke, I'll bet the Kosovars are wondering that about their strange, proscriptive Canadian liberators. What kind of fools are they?

\section{Up in smoke}

Stan Shatenstein responded in a letter to the National Post dated Fune 8, 1999.

We all have our tendencies but, according to the National Post's Mark Steyn, I have a Tendency, with a capital T. For Steyn, there is a risible "Shatenstein Tendency" that seems to miss "the essential difference between death from Slobo and death from smoking". And yet, when I took issue with Toronto Sun columnist Connie Woodcock, who has disparaged the Red Cross for not giving cigarettes to Kosovar refugees, I wrote: "We can count ourselves rather fortunate, in this country, that prevention of tobacco use remains the biggest health crisis we face, though it is a huge one. No one in Canada would rather confront the daily prospect of bombardment, displacement, rape, torture, and murder."

What exactly did I miss? Arguably the most violent century in history is ending with one of its most inarguably horrible, bestially obtuse conflicts. That still doesn't contradict my point that, while the "tragedy of Kosovo is near unspeakable, ... so is that of tobacco".

Steyn, on the other hand, gets it wrong when he writes that if "you decide to nip round the back of the barn for a quiet smoke, your diminished life expectancy is the conscious choice of a free individual". Sure, smokers tell themselves that all the time. "It's minus 40 with the wind chill factor, but I'm freely choosing to deliver this hit of nicotine to my brain, thus activating neurons in the mesolimbic system, thereby secreting dopamine and making me feel freely good." Yes, all the time.

For the most part, it's kids, not adults, who start smoking, and most young people show remarkably little insight into their own mortality. The young "nippers" at the back of the barn are choosing to be cool, but they're not expressly trying to die young.

Steyn celebrates the smoke shrouded mystique of Edward R Murrow and Humphrey Bogart, claiming how romantic it would have been to share a "narrow low-ceilinged windowless corridor" with them. Now, nobody should airbrush the smoke out of Murrow's seminal reports, and Bogie and Bacall wouldn't be the same without their shared match, but let's not get giddy here. Murrow and Bogart were both 57 when they died. Would you like the details of Bogart's oesophageal cancer, Mr Steyn? How about the spread of Murrow's lung cancer to his brain? 
So I reiterate my support of the decision by the Red Cross. A health agency has rightly refused to get back into the tobacco procurement business, something it had done during the second world war and other military conflicts. The Red Cross would still distribute cigarettes donated by another agency or association. Not exactly "Craven, eh?", as Steyn unoriginally puts it.
By the way, though we've never met, Steyn refers to me by my first name, presumably in some paternalistic or avuncular display of affectionate condescension. I will have none of it, Mr Steyn. There may be, as you say, a "Shatenstein Tendency", but there is not a "Steyn Way". That would be a blunt instrument, hitting only wrong notes, and playing badly out of tune.

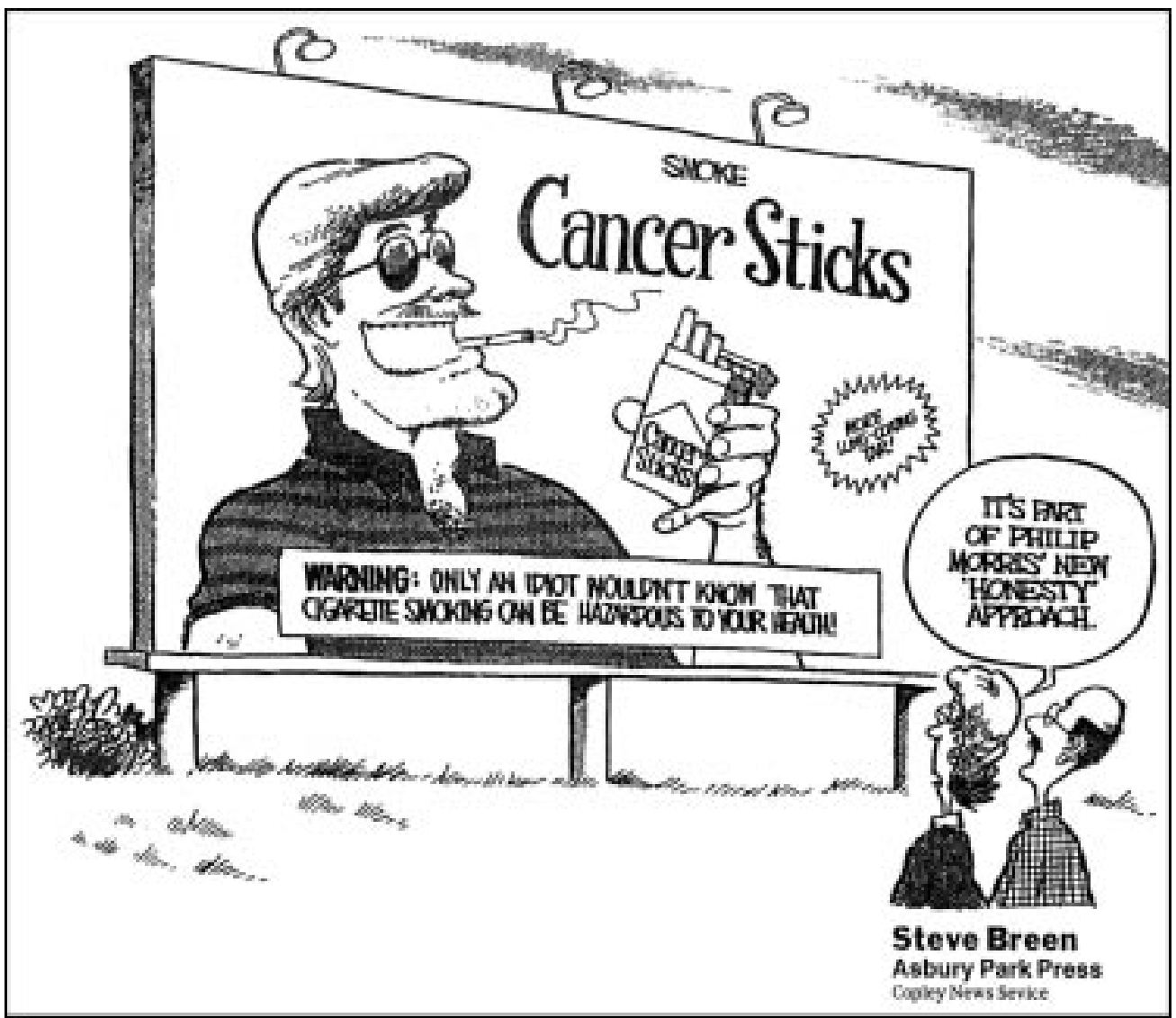

